\title{
Designing Educational Objectives in the Aspect of Innovative Activities of the Motor Transport Profile
}

\author{
Galina Bukalova ${ }^{1 *}$, and Elena Khovanskaya ${ }^{1}$ \\ ${ }^{1}$ Orel State University, 302026 Orel, Russia
}

\begin{abstract}
The implementation of innovation development strategies is a prerequisite for the effective functioning of modern transport complex enterprises. The need for innovation activities, formed in the sphere of profile production, actualizes the orientation of the educational process of the university on the formation of the graduates' readiness for active participation in industrial innovation activities. The multidimensional nature of innovation activities causes the application of interdisciplinary and competence approaches as a methodological basis for the design of educational goals. The student's understanding of their own professional identity is a prerequisite to achieve effective preparation for core innovation activities. The pedagogical potential of projective teaching, on the basis of the generalized structural composition of the innovation process, corresponds to the productive implementation of the innovation-oriented educational process of the engineering profile.
\end{abstract}

\section{Introduction}

Techno-technological and organizational innovations are the main factor determining the economic success of a motor transport enterprise. In the conditions of modern aggravation of competition in the market of motor transport services, the success of production activity is determined by the ability of the engineering and technical personnel of an enterprise to create perceive and use various innovations. A specialist who is capable of creative realization of their production functions becomes a key figure of a motor transportation enterprise, which is developing according to an innovative type [1-4]. This provides the possibility of forming educational goals based on the structural components of the innovation process.

\section{Material and methods}

At the present time, there is a modification of the hierarchy of values of the professional qualities of the engineering corps: the priority is recognized not for narrow professional knowledge, but for innovation, creativity, initiative, which allows reacting complexly to changes in the company's external environment [6-8]. On the basis of a cause-effect

* Corresponding author: $\underline{\text { 57orleya@gmail.com }}$ 
relationship, the need for changes in the sphere of the university educational process has emerged. This becomes a source of further development of engineering education of the motor transport profile. Taking into account the multidimensional nature of innovation in the field of motor transport production, the preparation of students for this activity should also be multifaceted. In view of this, it is expedient to select a systemic, competence and interdisciplinary approach to the design of educational goals, which reflect the graduates' readiness to innovate [9]. At the same time, the desire to achieve the optimality of the projected educational goals assumes a clear singling out of functional boundaries for the preparation of students in the technical and technological, economic and social spheres. According to the approach we develop, one of the main conditions for preparing graduates of a university for effective innovation activity is their awareness of their own professional identity as a participant in innovation activity. When designing educational standards reflecting the readiness for innovative activity, one cannot ignore the need for its harmonization with the economic imperative. Prior to understanding of students mastering the methodology of engineering innovation, it is advisable to convey the proposition that the idea of an innovative economy presupposes "... technologicalization and commercialization of intellectual activity" [2].

\section{Theory}

The context of this paper suggests addressing the concept of "innovation" as a process of production change. Researchers distinguish the innovations of management, production, financial, marketing, personnel, etc. $[4,5,10,18]$. The focus of attention of our article is focused on the division of innovations in the field of motor transport activities into technicaltechnological and organizational-social. Consideration, in the context of this article, of the concept of "innovation" as a process makes it possible to highlight the social and production problem of resistance of the personnel of the enterprise to the introduction of innovations [3, 16]. At the same time, the technology of intellectual activity is understood as a purposeful transformation of fundamental knowledge into a form of technological solutions. A professional identity is manifested in an emotionally expressed perception of the student's own conformity to the professional community of participants in innovation activities [11, $12,21]$. In general scientific understanding, professional identity is interpreted as the most important criterion for the formation of a professional, associated with inclusion in the profession, the acceptance of professional values [16, 19].

\section{Results and Discussion}

The engineering and technical personnel of a motor transport complex are to a large extent formed from graduates of the university who got professional training of the bachelor's degree. In view of this, it is expedient to orient the training in the direction "Operation of transport-technological machines and complexes" not only to use knowledge and skills of professional activities, but also to prepare for the active inclusion of service centers in innovative processes. The vehicle maintenance market manifests itself as a rigid constraint on innovation. The most important criterion of market efficiency in this case is the rate of profit extraction. From this it follows that graduates of the university, focused on innovation, should have the readiness to develop technology based on innovative ideas. Because of this, the ability of university graduates to maximize the scientific validity of innovative ideas and their willingness to develop clear technologies for the introduction of innovations that increase the efficiency of production processes should be presented in the status of 
educational standards so that students will, to the extent necessary, master the techniques for ensuring the technological innovation.

Organizational and social innovations assume changes in the organizational and managerial structure of the enterprise and the functions of officials. The introduction of organizational innovations inevitably violates the formed production interaction between workers and working groups. It is known that this leads to the development of resistance from the personnel of the enterprise involved in innovative transformations [11]. One of the founders of organizational and managerial science, $\mathrm{T}$. Burns outlined the following reasons for the resistance of personnel to the introduction of innovations: a vague idea of the objectives of innovation; the staff did not get a substantiation for the need for proposed changes; erroneous choice of methods of implementation; staff misunderstanding of the consequences of changes; the staff's perception of innovations as a source of threat to their official position; lack of methodological recommendations for innovation [17, 18]. Accordingly, students who were trained for innovation should master the competence of mentoring; readiness for methodical activity; the ability to form a positive moral and psychological climate of working groups.

According to the approach, which we develop, one of the main conditions for preparing a graduate of a higher education institution for effective innovative activities is the recognition of their own professional identity as a participant in innovation activities [12]. The professional identity of the profile innovation activities can also be presented as a product of professional and personal development of the student. In view of the high demand for the ability of engineering and technical personnel to innovate, professional identity as a personal resource must become the basis for student's effective learning activities.

In essence, the identity of professional innovation is the result of student's acceptance, at the psychological level, of the value positions of the participant in the production activity of this kind. Formation of the student's understanding of their own identity of this kind creates conditions for their self-orientation to develop the system of competencies necessary for the fruitful implementation of core innovation activities.

Preparation of engineering students for innovative production activities should be oriented in accordance with the generalized structural composition of the innovation process so that students at the level of training activities have the experience of mastering the implementation of the innovation process on the basis of conditional innovation development of a certain element of profile production. The use of the generalized structural composition of the innovation process [20] for the corresponding orientation of the educational process can be represented as follows.

The structural element of the innovation process - fundamental research focuses the content of the educational process on the presentation of certain theoretical positions. Acceptance of educational goals reflecting the willingness to innovate in the status of educational standards will provide students with the idea that theoretical knowledge is the basis of the innovation process, each element of which is based on certain scientific positions.

Educational goals reflecting readiness for applied research, as a structural element of the innovation process, orient students to "reify" knowledge as the embodiment of the results of fundamental research.

Such an element of the innovation process as the practical use of innovations can be presented in individual tasks performed by students in the course of production practice. For example, a training assignment may contain a requirement to identify the conformity of the technical, technological and organizational conditions of a basic motor service center with the possibility of realizing a certain innovation.

Commercial implementation of innovation as an element of the innovation process is actualized by educational goals, which are implemented by the content of educational 
disciplines reflecting the provisions for the commercialization of production activities in the field of a motor transport complex.

Examples of competencies that reflect the ability to innovate are:

- willingness to analyze production situations in order to identify "weak links" that require modernization;

- the ability to determine the most productive methods and ways to improve the elements of the production process;

- the ability to structure the process of innovation, including the use of an architectural approach;

- the ability to determine objectively the economically feasible volumes of production resources that ensure the introduction of innovation;

- willingness to substantiate the social significance of innovation;

- own modeling methods, including analysis of the level of reliability;

- the ability to draw up a project for the implementation of innovation, including control of the process approach.

As the projected educational goals of preparation for core innovative activities, it is also expedient to identify specific professional-important personal qualities, such as:

- intellectual activity (manifestation of interest in information related to the progressive profile professional activity, the ability to correlate disparate information with the problem being solved, the ability to adapt the decisions taken in obtaining new information, etc.)

- innovativeness (propensity to creative activity, the ability to generate initiative innovative ideas for practical problem solving, to demonstrate research activities);

- high communication skills (the ability to interact productively with partners of various levels of professional training, the ability to perceive the ideas of partners, the possession of a wide range of information and communication technologies);

- leadership (the ability to effectively convince, the ability to involve partners in the field of their ideas, readiness for personal responsibility for the productivity of decisions);

- achievement motivation (the ability to be proactive in resolving problems, to perceive the outcome of solving problems as personally significant, to establish the goals of intermediate elements of activities to solve the problem);

- stress resistance in the presence of uncertainty conditions.

It is known that not all people have the ability to innovate [10]. This fact points to the need for careful selection of students on the criteria of preparedness and motivation to learn innovation activities. It is necessary to create a specially organized educational environment, which would identify among the students most capable of innovation in order to further develop their ability to innovate through the organization of individual work. But this is a broader pedagogical problem with respect to the context of this article. However, the above list of competences and professionally important personal qualities can be used as the basis of a theoretical scheme for a separate pedagogical empirical study of students' readiness for mastering the innovative activities of an engineering profile.

\section{Conclusion}

For the system of engineering motor transport education, the phenomenon of selfdevelopment is characteristic. The impetus for this development is the identified need for modern motor production in labour resources, which are capable of carrying out innovative activities.

The educational process is managed through educational purposes. The multidimensional nature of the projected educational goals determines the multifaceted nature of the content of the educational process, aimed at preparing students for industrial innovation. Purposefulness 
of preparation for innovative production activities can be ensured as a result of its formalization through the creation of an appropriate educational and methodical complex integrating related academic disciplines [9, 13-15]. And the generalized structural composition of the profile innovation process can serve as a basis for integration. The administrative approval of the educational and methodological complex ensures the normative status of the purposeful orientation of the educational process to prepare for innovative production activities.

\section{References}

1. V.P. Solovyov, Yu.A. Krupin, T.A. Pereskokova, Obrazovanie dlja innovacionnojj ekonomiki [Education for an innovative economy], StaryOskol: TNT. (2014)

2. A.I. Chuchalin, Modernizacija jekonomikii povyshenie kachestva inzhenernogo obrazovanija [The modernization of the economy and the improvement of the quality of engineering education]. Almamater, 11, pp. 12-18 (2011)

3. A. Kosyakov, U. Swit, S. Seymour, S. Beamer, Sistemnaja inzhenerija. Principy I praktika [System Engineering. Principles and practices], Moscow: DMK-Press (2014)

4. N.I. Lapin, Teorija I praktika innovatiki [Theory and practice of innovation], Moscow: Universitetskaja kniga, Logos, 320 p. (2008)

5. A.N. Asaul, et al., Modernizacija jekonomiki na osnove tehnologicheskih innovacij [Modernization of the economy on the basis of technological innovations], SPb: ANO IPEV (2008)

6. Metodicheskie rekomendacii po razrabotke osnovnyh professional'nyh obrazovatel'nyh program I dopolnitel'nyh professional'nyh programm s uchetom sootvetstvujushhih professional'nyh standartov, utverzhdennyh Ministrom obrazovanija Rossijskoj Federacii ot 22.01.2015 №DL - 01/05vn [Methodical recommendations for the development of basic professional educational programs and additional professional programs, taking into account the relevant professional standards approved by the Minister of Education of the Russian Federation from 01/22/2015 № DL-01 / 05vn.], URL: http: // fgosvo.ru/support/43/5/8/.

7. V.A. Ivanyushina, D.A. Aleksandrov, I.L. Musabirov, Struktura akademicheskoj motivacii: ozhidanijai sub'ektivnyecennosti osvoenija universitetskogo kursa [Structure of Academic Motivation: Expectations and Subjective Values of Mastering the University Course]. Vopros yobrazovanija [Education Issues], 4, pp. 229-250 (2016)

8. V.I. Podlesnykh, Reformirovanie vysshego obrazovanija na osnove zameshhenija tehnologicheskogo uklada (novye podhody I metody) [Reform of higher education on the basis of the replacement of the technological order (new approaches and methods)], Moscow: INFRAM (2014)

9. G.V. Bukalova, Conceptual basis for the standardization of the result of professional education of a technical profile. Monograph, Orel: State University - UNPK (2014)

10. J. Pfeffer, R. Sutton, Dokazatel'nyj menedzhment: novejshaja koncepcija upravlenija ot Garvardskoj shkoly biznesa [Hard Facts, Dangerous Half-Trutha, and Total Nonsense: Profiting from Evidence-Based Management], Moscow: Eksmo. (in Russian) (2008)

11. N.L. Ivanova, E.P. Popova, Professionaly i problema vnedrenija innovacij v vuze [Professionals and the problem of innovation in the university]. Voprosy obrazovanija [Educationissues], 1, pp. 184-206 (2017) 
12. N.L. Ivanova, Professional'naja identichnost' $v$ sovremennyh issledovanijah [Professional Identity in Modern Studies]. Voprosy psihologii

[QuestionsofPsychology], 1, pp. 89-101. (2008)

13. Yu.G. Tatur, Vysshee obrazovanie: metodologija i opyt proektirovanija [Higher education: methodology and design experience], Moscow: Universitetskaja kniga, Logos (2012)

14. G.V. Bukalova, Obrazovatel'nye normativy - osnova formirovanija mezhdisciplinarnogo integrativnogo modulja [Educational standards are the basis for the formation of an interdisciplinary integrative module]. Inzhenernoeo brazovanie [Engineerin geducation], 20, pp.114-119 (2016)

15. F.A. Kazin, S. Hagen, A.G. Prichislenko, A.N. Zlenko, Obuchenie predprinimatel'stvu s ispol'zovaniem instrumentov pozitivnoj psihologii i social'nogo proektirovaniya, Voprosy obrazovaniya /Educational Studies Moscow, 3. pp. 110-131 (2017)

16. P. Petersen, E. Baker, B. McGaw, Diversity in Higher Education, (eds) International Encyclopedia of Education, 4, Oxford: Elsevier, P. 347-353 (2010)

17. R.S. Baker, P.S. Inventado, Educational Data Mining and Learning Analytics, J. A. Larusson, B. White (eds) Learning Analytics. New York: Springer. pp. 61-75. (2014)

18. T. Burns, J. Stalker, The Management of Innovation, Oxford: Oxford University Press. (1996)

19. Granello, D.H, Young, M. E. Counseling Today: Foundations of Professional Identity. 2011,Upper Saddle River, NJ: Pearson.

20. F. Damanpour, Organizational Innovation: A Meta-Analysis of Effects of Determinants and Moderators, Academy of Management Journal, 34 (3), P. 558-559 (1991)

21. Ed. J. Paulo Davim, Engineering Education, Chandos Publishing (2015) 